DOI https://doi.org/10.18551/rjoas.2021-03.12

\title{
DETERMINANTS OF INPUTS-OUTPUT RELATIONSHIP OF YAM PRODUCTION IN GBOYIN LOCAL GOVERNMENT AREA OF EKITI STATE, NIGERIA
}

\section{Ariyo Oluyinka Christopher ${ }^{\star}$}

Department of Entrepreneurship and Innovative Agriculture, Federal College of Forestry Mechanization, Afaka, Kaduna \& Forestry Research Institute of Nigeria, Ibadan, Oyo State, Nigeria

\author{
Usman Mohammed Bello \\ Federal College of Forestry Mechanization, Afaka, Kaduna \& Forestry Research Institute \\ of Nigeria, Ibadan, Oyo State, Nigeria

\section{Olagunju Olubukola Eden} \\ Department of Entrepreneurship and Innovative Agriculture, Federal College of Forestry \\ Mechanization, Afaka, Kaduna \& Forestry Research Institute of Nigeria, Ibadan, Oyo State, \\ Nigeria
}

\section{Ariyo Mary Oluyemisi}

Department of Horticulture and Landscape Management, Federal College of Forestry Mechanization, Afaka, Kaduna \& Forestry Research Institute of Nigeria, Ibadan, Oyo State, Nigeria

\author{
Ademuwagun Adebola Abimbola \\ Department of Basic Sciences and General Studies, Federal College of Forestry \\ Mechanization, Afaka, Kaduna \& Forestry Research Institute of Nigeria, Ibadan, Oyo State, \\ Nigeria \\ *E-mail: ask4ariyo@yahoo.com \\ ORCID: 0000-0001-8512-9433
}

\begin{abstract}
The determinants of input- output relationship of yam production was carried out in Gbonyin Local Government Area of Ekiti State with the aim of having better understanding of relationship between the inputs and output of yam. Multistage sampling techniques were used for the study. A total number of 140 respondents were randomly selected from four villages. Questionnaires were administered to the respondents by interview method and the data collected were analysed with descriptive statistics and multiple regression analysis. The results of the study showed that both males and females are involved in yam production in the study area, age between 21-70 years, married with household size of 1- 10 members with the highest faming experience of 1- 10 years and farm size of 1- 5 hectares. Majority had formal education (primary, secondary and tertiary education) and had no access to loans. The coefficient of both fertilizer and farm size were significant at $(P<0.001)$, labour at $(P<0.05)$ while the coefficient of seed was significant at $(P<0.10)$ probability level, thus played crucial roles in determining yam output. The problems facing yam production in the study area are inadequate capital, high cost of inputs, incidence of pests and diseases, inadequate planting materials, inadequate storage facilities, poor soil facility, poor produce price, poor transportation facilities, inadequate extension services, inadequate farmland and inaccessibility to farm inputs. The study conclude that farm inputs such as planting materials (yam miniset and seed yam), fertilizers and insecticides etc should be made available by the government and non-governmental organizations (NGOs) at a subsidized rate to the farmers. Also, farmers should come together and form cooperative societies where they will pool their resources together for members to obtain loans at very low interest rates to finance and expand their output.
\end{abstract}




\section{KEY WORDS}

Determinants, multistage sampling, farmers, input-output, coefficient.

Yams are member of the genus dioscorea which contain about 600 species of which only six are important as staples in the tropics (Coursey, 1969 and Hahn et al., 1993). The economically important species grown are Dioscorea rotundata (white guinea yam) $D$. alata (yellow yam), D. bulbifera (aerial yam) $D$. esculenta (Chinese yam) and $D$. dumenterum (trifoliate yam) (Piu and Odjuvwuederhie, 2006). According to Kathryn et al., (2012), the most cultivated species of yam (Dioscorea $s p$.) are white yam (D. rotundata), yellow or Guinea yam $(D$. cayenesis) and water yam $(D$. alata).Yam serves as staple food in many tropical and even sub-tropical countries of the world. Yam contributes more than 200 dietary calories per capita daily for more than 150 million people in West Africa and also an important source of income generation and trade (Reuben and Barau, 2012).

World yam production amounts to 30 million tonnes annually and $90 \%$ are grown in the yam production regions of West Africa (FAO, 2002). According to International Institute for Tropical Agriculture, Yam is grown on 5 million hectares in about 47 countries of the world with Nigeria as the leading producer (IITA, 2009). Because of the high socio-cultural value attached yam, all farmers grow yam, though in much lower quantity in the North, since the arid climate is not well-suited for yam production (Kathryn et al., 2012 and Man Abdullahi 2015). While yam is grown in all parts of the country, yam production is concentrated in the forest, derived and southern Guinea savannah agro-ecological zones in the central and southern part of the country (Fu et al., 2011).

The States with the highest production (Taraba, Benue and Niger) are not those with the highest yields (Nassarawa, Osun, Ekiti, Ondo and Imo). High production States have larger areas under cultivation, suggesting that yam production may be more intensive in the high yield States. The high yield States - Osun, Ekiti, and Ondo - fall in the rain forest zone which has higher levels of humidity and rainfall that are more conducive to yam growth (Kathryn et al., 2012 and Man Abdullahi 2015). In most years between 1995 and 2006, the rain forest zone produced the highest yields (Kathryn et al., 2012 and Man Abdullahi 2015). The highest producing States - Taraba, Benue, and Niger States - are found in the open woodland and savannah zones (Dumet and Ogunsola, 2008).

Yam production in Africa is constrained by several factors including the limited availability and loss of planting material as well as the high cost of labour for operations such as land preparation, staking, weeding, harvesting and storage. Planting materials account for about $50 \%$ of the cost of production and the cost of labour accounts for over $40 \%$ (Nweke et al., 1991). The shrinking area of fertile land and the biotic stress imposed by viruses, fungi, nematodes and insects adversely affect crop production and reduce profit. In most parts of Nigeria, up to $30 \%$ (3-5t/ha) of the previous harvest may be used to plant a new crop.

The hectares of land devoted for yam production has been increasing with corresponding increases in the usage of inputs. The resources that are employed by yam farmers range from land to seed yams, chemicals, fertilizers and labour. However, the increase in output has not been commensurable with the inputs usage (Jonathan and Anthony, 2012). Against this backdrop, there is need for a better understanding of the relationship between the inputs and output of yam production in the study area. Moreover, no research has addressed the relationship between the inputs and output of yam production in the study area. The specific objectives of this study are to: describe the socio economics characteristics of the respondents, determine the relationship between inputs and output of yam production and identify problems facing yam production in the study area.

\section{METHODS OF RESEARCH}

The study was conducted in Gboyin Local Government Area of Ekiti State in the southwestern Nigeria, in the humid tropics. The Local Government was carved out from Ekiti East Local Government Area (LGA) on 1st of October, 1996 to be one of the sixteen local governments in Ekiti state. It has it's headquarter council secretariat cited at the eastern part 
of Ode Ekiti via Egbe-Isinbode road. The Local Government Council Area which was located in the North Eastern part of Ekiti State has a landed area of 391 square kilometer and a population of 148,193 as at the 2006 census. Ekiti State is located between latitude $70^{\circ} 36^{\prime} \mathrm{N}$ \& $70^{\circ} 39^{\prime} \mathrm{N}$ and longitude $50^{\circ} 32^{\prime} \mathrm{E} \& 50^{\circ} 32^{\prime} \mathrm{E}$ of the Greenwich meridian. The LGA is made up of eight major towns and several villages. It shared territorial boundaries with seven LGAs viz; Ise/Emure, Ekiti East, Ikole, Irepodun/Ifelodun and Ado Ekiti in Ekiti State, and AkokoNorth/West of Ondo State. The points of attraction in the area of study are Oloke rock at Ode, Apariko dam at Aisegba and others (ESD-ICT, 2015). The people are mostly farmers producing food crops such as yam, cassava, rice, potatoes, cocoa, Palm tree etc.

Multistage sampling technique was used for this study. The first stage was the purposive selection of Gbonyin Local Government area because of intensive production of yam in the study area. The second stage was the random selection of four villages within the local government area. The villages are Ode- Ekiti, Agbado, Aisegba and llumoba. In the third stage, 35 yam farmers were selected from each village at random to make total sample size of 140 respondents that was used for the study.

Primary data were collected with the use of semi-structured questionnaire which consists of open and closed ended questions. The questionnaire was structured in line with the objectives of the study and subjected to validity and reliability test. The questionnaire was administered to the respondents by personal interview. The respondents were probed to obtain more information on the subject matter

The tools of analysis used to achieve the objectives of the study were descriptive statistics and multiple regression analysis. Descriptive statistics was used to analysed the socio- economic characteristic of the respondents, and to identify problems facing yam production in the study area while multiple regression analysis was used to determine the input-output relationship of yam production. Three functional forms were specified: Linear, Semi log and Double log (cob Douglas) function.

The implicit form of the model was specified as:

$$
Y=f\left(X_{1}, X_{2}, X_{3}, X_{4}, X_{5}, U\right)
$$

Where:

$\mathrm{Y}=$ Independent variable (Output of yam in $\mathrm{Kg}$ );

$\mathrm{X}_{1-5}=$ Explanatory variables;

$\mathrm{U}=$ Random error term.

The explicit forms of all the models were stated below. Linear function:

$$
Y=a+b_{1} X_{1}+b_{2} X_{2}+b_{3} X_{3}+b_{4} X_{4}+b_{5} X_{5}+U
$$

Semi-log function:

$$
Y=\ln a+b_{1} \ln X_{1}+b_{2} \ln X_{2}+b_{3} \ln X^{3}+b_{4} \ln X_{4}+b_{5} \ln X_{5}+\ln U
$$

Double log (Cobb-Douglas):

$$
\ln Y=\ln a+b_{1} \ln X_{1}+b_{2} \ln X_{2}+b_{3} \ln X_{3}+b_{4} \ln X_{4}+b_{5} \ln X_{5}+\ln U
$$

Where:

$\mathrm{Y}=$ Output of yam $(\mathrm{kg})$

$X 1=$ Quantity of seeds used $(\mathrm{kg})$;

X2 = Quantity of Fertilizer (kg);

X3 = Labour used (Man-days);

X4 = Farm size (ha);

$X 5=$ Chemicals (liters);

$\mathrm{U}=$ Error term. 


\section{RESULTS AND DISCUSSION}

The socio- economic characteristics of the respondents was presented on table 1 . It showed that $72.86 \%$ of the respondents are males and $27.14 \%$ are females. This showed that males are more in the production of yam in the study area. This could be due to the fact that yam production is labour intensive and requiring substantial energy and time. The finding is in agreement with Nlerum (2012) who noted that yam production in Rivers State, Nigeria was dominated by males and it could be attributed to the energy demanding activities involved in yam production which require men who are naturally endowed with abundant strength necessary for such jobs. Izekore and Olumese, (2010) attribute male dominance in yam production to the more labor-intensive nature of the crop's cultivation relative to other crops.

In terms of the age of the respondents, majority (41.43\%) are within the age of $41-50$ years. This was followed by $28.57 \%, 18.57 \%$ and $4.29 \%$ who are within age range of $31-40$, 51-60 years and $21-30$ years respectively. Only $7.14 \%$ are above 61 years but not more than 70 years. The average age was 45.5 years. This is in line with the findings of Ugwumba and Omojola, (2012) and Man Abdullahi (2015) who both found the average age of yam farmers in Ipao-Ekiti, and selected local government in Niger State, Nigeria indicate that they were still in their active productive years. However, findings about average age are inconsistent. Agbaje et al (2005) found the average age of yam producers to be 52.5 years while Fu et al., (2011) determined an average age of 39.2 years. Ike and Inoni, (2006) presume that due to the arduous nature of yam cultivation; older farmers are less productive than younger farmers.

With respect to marital status, $75.71 \%$ of the respondents are married, $15.71 \%$ single and $8.57 \%$ are divorced. This showed that majority of the respondents are married. The implication of this is that, there is likely to be more family labour available for yam production. This agrees with the findings of Augustine et al., (2008) who found that over $70 \%$ of the married couples were involved in yam production in South Eastern Nigeria.

Formal education is an essential tool for the adoption of modern production technologies and effective communication system that encourages increase in the productivity of any agricultural venture (Ugwumba and Omojola, 2012). Majority of the respondents had secondary school education, representing $52.14 \%$. The percentage of respondents that had primary and secondary education was $27.86 \%$ and $15 \%$. Only $5 \%$ of the respondents had adult education. The high level of literacy in the study will help the yam farmers to adopt new technologies that will improve their production.

Majority $(68.57 \%)$ of the respondents had household size between 1-5 members while only $31.43 \%$ had family members between 6-10. The average household size of the respondents was 6 . This showed that the respondent had relatively large household size. Okoye et al., (2010) and Udensi et al., (2011) reported that a relatively large household size are more likely to provide more labour required for farm operations such as weed control, fertilizer application. Though large household size may not guarantee for increased labour efficiency since family which comprises mostly children of school age are always in school. Banmeke (2010) asserts that family size is an important index in any rural development intervention which can affect the outcome of such intervention.

The years of farming experience revealed that $65 \%$ of the respondents had the highest farming experience of $1-10$ years. $24.29 \%$ and $10.71 \%$ had $11-20$ and $21-30$ years of experience respectively. According to Oluwatayo et al., (2008); Izekore and Olumeze (2012), experience farmers would be more efficient, have a better knowledge of climatic conditions and are thus expected to run a more efficient enterprise

With respect to farm size, the greater majority of the respondents $83.57 \%$ had farm size between $1-5$ hectares while only $16.43 \%$ cultivated above five hectares of yam. It is important to state here that the farms are fragmented into patches in various locations. The findings is contrary to the finding of Kolawole and Ojo (2007) who noted that Nigerian agriculture involves small scale farmers scattered over wide expense of land areas with small holders ranging from $0.5-3.0$ hectares. 
The arduous nature of yam cultivation requires most yam farmers to supplement family labour with hired labour. Labour constitutes the largest proportion of yam production costs (Kathryn et al., 2012). The sources of labour showed that family labour formed the highest labour used by the respondents, constituting $49.29 \%$. The use of family and higher labour together had $32.86 \%$ while higher labour was the lowest source of labour employed with $17.86 \%$. This was similar to observation of Rahman and Mali (2011) that majority of the small scale farmers are poor and usually utilize family labour. However, this was contrary to a study in Delta, Nassarawa and Benue states where $73.96 \%$ of seed-yam producing households used both family and hired labour to fulfil production requirements. However, the proportion of yam farmers who relied mostly on family labour $(3.13 \%)$ was relatively small; authors attribute this to higher school attendance rates that mean children are not available to work on the farm (Asumugha et al., 2007). In another survey of seed yam producers, the majority of farmers $(71.6 \%)$ used both family and hired labour on their minisett farms. Only $16.6 \%$ used family labour alone, while $11.6 \%$ used hired labour alone. This same study reported that some farmers hired migrant labourers that were mostly from Benin and Niger to fulfil production requirements (Eyitayo et al., 2010).

Table 1 - Socio- economic characteristics of the respondents

\begin{tabular}{|c|c|c|}
\hline Socio- economic characteristics & Frequency & Percentage \\
\hline \multicolumn{3}{|l|}{ Gender } \\
\hline Male & 102 & 72.86 \\
\hline Female & 38 & 27.14 \\
\hline \multicolumn{3}{|l|}{ Age } \\
\hline $21-30$ & 6 & 4.29 \\
\hline $31-40$ & 40 & 28.57 \\
\hline $41-50$ & 58 & 41.43 \\
\hline $51-60$ & 26 & 18.57 \\
\hline $61-70$ & 10 & 7.14 \\
\hline \multicolumn{3}{|l|}{ Marital status } \\
\hline Married & 106 & 75.71 \\
\hline Single & 22 & 15.71 \\
\hline Divorce & 12 & 8.57 \\
\hline \multicolumn{3}{|l|}{ Educational level } \\
\hline Primary education & 39 & 27.86 \\
\hline Secondary education & 73 & 52.14 \\
\hline Tertiary education & 21 & 15 \\
\hline Adult education & 7 & 5 \\
\hline \multicolumn{3}{|l|}{ Household size } \\
\hline $1-5$ & 96 & 68.57 \\
\hline $6-10$ & 44 & 31.43 \\
\hline \multicolumn{3}{|l|}{ Farming Experience } \\
\hline $1-10$ & 91 & 65 \\
\hline $11-20$ & 34 & 24.29 \\
\hline $21-30$ & 15 & 10.71 \\
\hline \multicolumn{3}{|l|}{ Farm size } \\
\hline $1-5$ & 117 & 83.57 \\
\hline 5 above & 23 & 16.43 \\
\hline \multicolumn{3}{|l|}{ Land ownership } \\
\hline Inheritance & 104 & 74.29 \\
\hline Rent & 28 & 20 \\
\hline Purchased & 3 & 2.14 \\
\hline Hired & 5 & 3.57 \\
\hline \multicolumn{3}{|l|}{ Sources of Labour } \\
\hline Family labour & 69 & 49.29 \\
\hline Hired labour & 25 & 17.86 \\
\hline & 46 & 32.86 \\
\hline \multicolumn{3}{|l|}{ Accessibility to Loan } \\
\hline Yes & 23 & 16.43 \\
\hline No & 117 & 83.57 \\
\hline
\end{tabular}

Source: Computed from field survey data, 2018. 
Smallholders often have difficulty covering the high cost of planting materials and inputs required to achieve greater yields, thus credit facilities are required for smooth farm operations. In term of accessibility to credit, $83.57 \%$ of the respondents do not have access to loan while only $16.43 \%$ had access to loan. Migap and Audu, (2012) in their Empirical Study on Yam Cultivation and Economic Development of Taraba State, a case study of Wukari Local Government Area found that $100 \%$ of yam farmers/traders had no access to credit facilities, $82 \%$ believed that increased access to credit facilities would improve yam cultivation. Another study revealed that $66 \%$ of farmers depend on their own capital to sustain yam production, while $29 \%$ depended on farmers' cooperative groups and only $1 \%$ benefitted from bank loans (Agbaje et al., 2005). The lack of access to loan facilities by the majority of respondents in this study will limit the strength of yam production in the study area.

The result of multiple regression analysis showed that Cobb- Douglas gave the best fit and was presented on Table 2. The model was chosen as the lead equation on the basis of econometric and statistical criteria such as the magnitude of coefficient of multiple determination $\left(R^{2}\right)$, significance of the individual explanatory variables as expressed by their $\mathrm{t}$-values, significance of the overall production functions as judged by $\mathrm{F}-$ value and appropriateness of the signs of the regression coefficient based on a priori expectations. The result revealed that the coefficients of all the variables included in the model are positively related to the output. This means that a unit increases in any of the variable holding others constant will lead to a unit increase in the total output of yam. The value of coefficient of multiple determinations $\left(R^{2}\right)$ is 0.735 . This implies that $73.5 \%$ of the total variation in the dependent variable is explained by the independent variables included in the model while the remaining $26.5 \%$ is attributed to random error. The coefficient of fertilizer and farm size were significant at $(P<0.001)$, labour at $(P<0.05)$ while the coefficient of seed was significant at $(P<0.10)$ probability level. This showed that all the variables (seeds, fertilizers, labour and farm size) included in the model are very crucial in the output of yam. The F- statistics of $48.63 \%$ obtained shows that the overall equation (model was statistically significant at $(\mathrm{P}<$ 0.001 ) probability level. With this result, the null hypothesis which says there is no significant relationship between the inputs and output of yam production was hereby rejected, meaning that the independent variables included in the model determines the output of yam produced. This simplifies the regression equation to: $\log Y=-4204.380+0.123 \log X 1^{*}+0.199 \log$ $X 2^{\star \star *}+0.126 \log X 3^{* \star}+0.702 \log X 4^{* \star *}+U i$.

Table 2 - Regression Analysis of Input- Output Relationship

\begin{tabular}{lll}
\hline Variables & Coefficient & t- values \\
\hline Constant term & -4204.380 & -1.338 \\
X $_{1}$ Seeds & $0.123^{*}$ & 1.797 \\
X $_{2}$ Fertilize & $0.199^{* \star *}$ & 2.922 \\
X $_{3}$ Labour & $0.126^{* *}$ & 1.916 \\
X $_{4}$ Farm size & $0.702^{* \star *}$ & 10.220 \\
F - statistics & $48.634^{\star * *}$ & \\
R - square & 0.735 & \\
Adjusted R - square & 0.720 & \\
\hline
\end{tabular}

Source: Computed from field survey data, 2018.

*** Significant at $0.01^{* \star}$ Significant at $0.05{ }^{\star}$ Significant at 0.10 .

The distribution of respondents based on the problems faced in yam production was presented on Table 3. All the problems presented such as inadequate capital, high cost of inputs, incidence of pests and diseases, inadequate planting materials, inadequate storage facilities, poor soil facility, poor produce price, poor transportation facilities, inadequate extension services, inadequate farmland and inaccessibility to inputs affects the production activities of famers in the study area. Eze (2000) identified inadequate infrastructure as a constraint for the development of agricultural production in south-eastern Nigeria. However, all the respondents had problems of inadequate capital, high cost of inputs, inadequate planting materials and inaccessibility to inputs, representing $100 \%$. 
Table 3 - Distribution of Respondents Based on Problems Facing Yam Production

\begin{tabular}{lll}
\hline Problems & Frequency & Percentage \\
\hline Inadequate capital & 140 & 100 \\
High cost of inputs & 140 & 100 \\
Incidence of Pests and Diseases & 130 & 92.86 \\
Inadequate planting materials & 140 & 100 \\
Inadequate storage facilities & 125 & 89.29 \\
Poor soil fertility & 105 & 75 \\
Poor produce price & 135 & 96.43 \\
Poor transportation facilities & 115 & 82.14 \\
Inadequate extension services & 100 & 71.43 \\
Inadequate farmland & 125 & 89.29 \\
Inaccessibility to inputs & 140 & 100 \\
\hline Total & $1395^{*}$ & \\
\hline
\end{tabular}

Source: Computed from field survey data, 2018. * Multiple responses.

The percentage of respondents that had problems of poor produce price and incidence of pests and diseases are $96.43 \%$ and $92.86 \%$. Equal number of respondents had problems of inadequate storage facilities and inadequate farmland each having $89.29 \%$. Problems of poor transportation facilities, poor soil fertility and inadequate extension services had $82.14 \%, 75 \%$, and $71.43 \%$ respectively. This is in line with findings of Ayanwuyi et al., (2011) which stated that yam farmer's perceived constraints to production include: declining soil fertility; lack of access to, or inadequate information about improved yam varieties; disease and pest attack; lack of access to inputs like seed yams and inorganic fertilizer; high production costs for planting materials and labour; and lack of access to credit.

\section{CONCLUSION}

It can be concluded from the findings of the study that both males and females are involved in yam production in the study area, age between 21-70 years, married with household size of 1-10 members with the highest faming experience of 1-10 years and farm size of 1- 5 hectares. Majority had formal education (primary, secondary and tertiary education) and had no access to loans. Factors such as seeds, fertilizers, labour and farm size are very crucial in determining yam production (output). The problems facing yam production are inadequate capital, high cost of inputs, incidence of pests and diseases, inadequate planting materials, inadequate storage facilities, poor soil facility, poor produce price, poor transportation facilities, inadequate extension services, inadequate farmland and inaccessibility to farm inputs.

\section{RECOMMENDATIONS}

Based on the findings of the study, the following recommendations among others are made:

- Farm inputs such as yam miniset and seed yam, fertilizers, insecticides, etc should be made available by the government and non-governmental organizations (NGOs) at a subsidized rate so that it can be affordable by the farmers;

- Transportation systems should be improved upon by renovating bad roads and construction of new ones by the government to provide effective transportation networks to the farmers in obtaining farm inputs and transporting the outputs to the market;

- Extension agents should be mandated by the Ministry of Agriculture at State and Federal level to have a regular visits and training on different techniques of yam production and also link farmers up to where they can obtain farm inputs at affordable prices;

- The farmers should come together and form cooperative societies where they will pool their resources together for members to obtain loans at very low interest rates to finance and expand their output. 


\section{REFERENCES}

1. Agbaje, G. O., Ogunsumi, L. O., Oluokun, J. A., and Akinlosotu, T. A. (2005). Survey of yam production system and the impact of government policies in southwestern Nigeria. Journal of Food, Agriculture \& Environment, 3(2), 222-229.

2. Asumugha, G. N., Ugwu, B. O., Aniedu, O. C. and Orkwor, G. C. (2007). Seed yam marketing in Nigeria: Determinants and constraints. Proceedings of the 13th ISTRC Symposium, 656-663.

3. Augustine, J. U., Anietie, I., Emmanuel, U. and Unyime, R.C. (2008). Socio-economic Factors Influencing Adoption of yam Minisett Technology in South Eastern Nigerian: A Probity Analysis. Indian Research Extension Education,8 (2\&3), 1-4.

4. Ayanwuyi, E., Akinboye, A. O., and Oyetoro, J. O. (2011). Yam Production in Orire Local Government Area of Oyo State, Nigeria: Farmer's Perceived Constraints. World Journal of Young Researchers, 1(2), 16-19.

5. Banmeke, T. O. A. (2010). Accessibility and utilization of Agricultural Information in the Economic Empowerment of Women Farmers in South Western Nigeria. Unpublished PhD Thesis, Department of Agricultural Extension and Rural Development, University of Ibadan, Nigeria.

6. Coursey, D. G. (1969). Ascorbic Acid in Ghana Yams, Journal of Food Science and Agriculture, 17: 446- 449.

7. Dumet, D. and Ogunsola, D. (2008). Yams: Regeneration guidelines. In M. E. Dulloo, I. Thormann, M. A. Jorge, \& J. Hanson (Eds.), Crop specific regeneration guidelines (pp. 17). Rome, Italy: CGIAR System-wide Genetic Resource Programme.

8. Eyitayo, O. A., Anthony, T. O. and Theresas, I. (2010). Economics of Seed Yam Production Using Minisett Technique in Oyo State, Nigeria. Field Actions Science Reports, 4(2010), 1-5.

9. Eze, S. O. (2000): Factor limitary infrastructural development and extension contacts in farming communities in south-eastern Nigeria. Journal of Agric-Business and Rural Development; University of Uyo, Akwa-lbom State. Vol. 2 Pp $103-109$.

10. Food and Agricultural organization (FAO). 2002. Statistical data. www.fao.org.

11. Fu, R. H. Y., Kikuno, H., and Maruyama, M. (2011). Research on yam production, marketing and consumption of Nupe farmers of Niger State, central Nigeria. African Journal of Agricultural Research, 6(23), 5301-5313. doi:10.5897/AJAR11.586

12. Hahn, S. K., Osiru, D. S. O., Akoroda, M. O., Atoo, J. A. (1993). Production of Yams, Present Role and Future Prospects. IITA Research Guide 46, IITA Ibadan, 36p

13. Ike, P. C., and Inoni, O. E. (2006). Determinants of Yam Production and Economic Efficiency among Small-Holder Farmers in South-eastern Nigeria. Journal of Central European Agriculture, 7(2), 337-342.

14. International Institute of Tropical Agriculture (IITA, 2009). Information handbook.

15. Izeko, O. B, and Olumeze, M. I, (2012). Determinant of yam production and profitability in Edo state, Nigeria. African Journal of General Agriculture. 6(4), 62-69.

16. Izekore, O. B., and Olumese, M. I. (2010). Determinants of yam production and profitability in Edo State, Nigeria. African Journal of General Agriculture, 6(4), 205-210.

17. Jonathan, R. and Anthony, D. B. (2012). Resource Use Efficiency in Yam Production in Taraba State, Nigeria. Journal of Agricultural Sciences, 3(2): 71-77.

18. Kathryn Bergh, Patricia Orozco, Mary Kay Gugerty, \& C. Leigh Anderso (2011). Yam Value Chain: Nigeria. Evans School Policy Analysis and Research (EPAR). EPAR Brief No. 207. Pp. $1-28$

19. Kolawale, O and Ojo, S. (2007). Economic Efficiency of Small Scale Food Crop production in Nigeria: A Stochastic Frontier Approach. Journal of Social Sciences.14 (2):123-30.

20. Man Abdullahi (2015). Profitability and Efficiency of Yam Production among Small Holder Farmers in Selected Local Government Areas of Niger State, Nigeria. An unpublished MSc thesis submitted to the Department of Agricultural Economics and Rural Sociology. Faculty of Agriculture Ahmadu Bello University Zaria, Kaduna State Nigeria, pp. 1-69 
21. Migap, J. P., \& Audu, F. (2012). Empirical Study on Yam Cultivation and Economic Development of Taraba State: Case Stud of Wukari Local Government Area. Journal of Business and Organizational Development, 4(6), 32-53.

22. Nlerum, F. E. (2012). Socio-economic characteristics as correlates of adoption among yam farmers in rural Ikwerre Area of Rivers state, Nigeria. Journal of Agricultural Extension, 2(2), 74-80.

23. Nweke, F. I. Ugwu. B. O., Aseidu, C. L. A, and Pay (1991): "Production Costs in The Yam-Based Cropping System of Southeastern Nigeria". Resource and Crop Management Program (RCMP) Research Monogram No.6. International Institute of Tropical Agricultural (IITA), Ibadan, Nigeria, pp 29.

24. Okoye, B. C., Asumugha, G. N. and Mbanaso, G. (2010). Cost and Return analysis of Cocoyam production at National Root crops Research Institute, Umudikwe, Abia state, Nigeria. 17363p. http://mpra.ub.uni-muenchen.de/17363.

25. Oluwatayo, I. B., Sakumade, A. B. and Adesoji, S. A. (2008). Resource use Efficiency of Maize Farmers in Rural Nigeria: Evidence from Ekiti State. World Journal of Agricultural Sciences 4: 91- 99.

26. Pius Chinwuba Ike and Odjuvwuederhie Emmanuel Inoni (2006). Determinants of Yam Production and Economic Efficiency among Small-Holder Farmers In South-eastern Nigeria. Journal of Central European Agriculture, vol. 7. No. 2, pp. 337-342

27. Rahman, S. A. and Mali, J. N. (2011). Price Responsiveness of Maize and Rice Farmers in Nigeria. The Nigeria Journal of Scientists Research 4(1): $45-49$.

28. Reuben, J and Barau, A. D. (2012). Resource use efficiency in yam production in Taraba state, Nigeria. Journal of Agricultural Science, 3(2): 71-77

29. Udensi. E., Gbassey, T, Ebere, U. F. G., Asumugha, C. E., Okoye, B .C., Okarter, C., Paul, I., Richardson, O. and Alfred, D. (2011). Adoption of selected improved cassava varieties among small holder farmers in South-Eastern Nigeria. International Journal of Food, Agriculture and Environment. 9(1): 329-335.

30. Ugwumba, C. O. A and Omojola, J. T. (2012). Socio-Economic Determinants and Profitability of Yam Production in Ipao-Ekiti, Nigeria. Journal of science and multidisciplinary research. Vol.4 December, 2012. 